\title{
Tackling COVID-19 Disinformation: Internal and External Challenges for the European Union
}

\author{
Sophie L. Vériter, ${ }^{a}$ Corneliu Bjola ${ }^{b}$ and Joachim A. Koops ${ }^{c}$ \\ anstitute of Security and Global Affairs (ISGA), University of Leiden, The \\ Hague, The Netherlands; University of Oxford, Oxford, United Kingdom \\ bUniversity of Oxford; Oxford Digital Diplomacy Research Group, Oxford, \\ United Kingdom \\ 'Institute of Security and Global Affairs (ISGA), University of Leiden, The \\ Hague, The Netherlands \\ s.l.veriter@fgga.leidenuniv.nl; corneliu.bjola@qeh.ox.ac.uk;j.a.koops@fgga. \\ leidenuniv.nl
}

Received: 12 June 2020; revised: 2 September 2020; accepted: 26 September 2020

\section{Summary}

The corona crisis is also a disinformation crisis for the global community in general, and for the European Union (EU) in particular. What is less clear is how adequate the EU's response to the 'infodemic' has been. This essay exposes the dangers of disinformation for the $\mathrm{EU}$, which have intensified in the context of the CovID-19 pandemic, and reviews relevant $\mathrm{EU}$ responses. It then zooms in on two challenges exacerbated by the corona crisis: one internal, revolving around the toxic effect of conspiracy theories, particularly the corona- $5 \mathrm{G}$ hoax; and one external, relating to the public diplomacy campaigns of competing geopolitical actors, especially China. The essay argues that the future of European stability will rest not only on ensuring societal resilience to disinformation and conspiracy theories but also on designing ethically guided preemptive mechanisms and confronting external sources of disinformation which jeopardise European health provisions, economic recovery and geoeconomic strength. 


\section{Keywords}

disinformation-conspiracytheories-publicdiplomacy-EU strategic communicationCOVID-19

\section{Introduction}

The corona crisis is also a disinformation crisis for the global community in general, and for the European Union (EU) in particular. As an expert from the European External Action Service (E EAS) Strategic Communication(StratCom) Division points out, 'It has been very clear that the information and manipulation of information [have] become a security problem.' ${ }^{1}$ What is less clear is how adequate the EU's response to the coronavirus 'infodemic' has been. In addition, the blurring between public diplomacy and harmful disinformation highlighted by the corona crisis raises ethical questions for the future of EU strategic communication.

This essay exposes the dangers of disinformation for the $\mathrm{EU}$, which have intensified in the context of the COVID-19 pandemic, and reviews relevant EU responses. It then discusses the prospects of $\mathrm{E} U$ strategic communication byconcentrating on two challenges exacerbated by the corona crisis: one internal the toxic effect of conspiracy theories on the EU public sphere, particularly the corona-5G hoax - and one external — public diplomacy campaigns of competing geopolitical actors, especially China. In conclusion, the essay argues that the future of European stability not only rests on ensuring societal resilience to disinformation and conspiracy theories but also on designing pre-emptive mechanisms and confronting external sources of disinformation which jeopardise European health provisions, economic recovery and geoeconomic strength.

\section{$2 \quad$ Challenges of Disinformation for Multilateral Approaches}

Building on the growing literature on this subject, this essay defines disinformation as the intentional and systematic manipulation of information deceiving a target audience to cause public harm, generate profit and/or advance political goals. ${ }^{2}$ Whilst disinformation is not novel, the digitalisation

1 Staff from the EEAS StratCom Division, interviewed in Brussels by the first author, July 2019.

2 See Bennet and Livingston 2018, 124; Freelon and Wells 2020, 145; HLEG 2018, 3. 
of information and communication has transformed its conduct and impact. As aptly put by Joseph Nye, 'What's new is not the basic model; it's the speed with which such disinformation can spread and the low cost of spreading it.'3 The recent upsurge in digital activities resulting from the CoviD-19 pandemic has heightened this phenomenon.

Both state and non-state actors are at the source of disinformation, which organisations, the media and individuals including public figures may then relay. Digital channels are particularly effective means of spreading disinformation because of the amplification mechanisms they present (e.g., bots, trolls, algorithms, echo chambers). Facebook is the platform of choice, primarily because of the massive audiences that it can reach relative to other networks. Disinformation materialises in different forms, commonly: 1) unsourced or false claims, 2) non-credible claims with sources, 3) claims based on unsourced or non-credible claims and 4) conspiracy theories. ${ }^{4}$ At the receiving end, disinformation mainly affects minority groups and thrives in socially unstable environments with vulnerable media ecosystems and contested institutions. The reception and relay of disinformation is thus closely linked to its environment; hence, the increasingly important role of online regulations.

Whilst the literature on the impact of false news and propaganda has expanded in recent years, research is still limited and theoretical answers are more advanced than empirics, especially in Europe. ${ }^{5}$ Empirical studies are, however, crucial to measure and understand the effect of disinformation (e.g., on voting behaviour) and to develop appropriate responses accordingly. Measuring the influence of such a volatile phenomenon is a difficult enterprise, which calls for mixed methods that take into account the quantity and quality of disinformation. Indeed, disinformation generates higher engagement than mainstream news, despite a smaller reach compared to established news brands. ${ }^{6}$

Among the nascent literature on the effects of disinformation, three trends emerge. First and foremost, disinformation is likely to increase polarisation, in particular along politically partisan lines, by spreading harmful conspiracy theories, radical and supremacist thoughts, Islamophobia, cynicism, racism, distrust or misogyny. ${ }^{7}$ Second, disinformation contributes to lowering trust in mainstream media and institutions, although these two variables appear to be

\footnotetext{
3 Nye 2018.

4 Bjola and Pamment 2016, 135 .

5 Freelon and Wells 2020; Tucker et al. 2018, 15 .

6 Fletcher et al. 2018, 4-5.

7 Faris et al. 2017; Jeangène Vilmer et al. 2018; Marwick and Lewis 2017.
} 
mutually reinforcing. ${ }^{8}$ Finally, disinformation poses a threat to democratic political processes by corrupting the integrity of electoral processes and undermining the democratic values which shape public policies, including in the health and science sectors. ${ }^{9}$

Disinformation has increasingly caught governmental actors' attention, yet they still struggle to respond to its evolving nature. Over the past five years, EU Member States have equipped the EEAS with three regional StratCom Task Forces. In 2018, the EU released a comprehensive Action Plan against Disinformation. Its measures focus on developing societal resilience through factchecking and public diplomacy and rely on voluntary abidance to non-binding rules such as a Code of Practice for online platforms. The limitations of this approach have become evident during the CoviD-19 pandemic, as Member States have struggled to collectively communicate and confront the 'infodemic'. Experts called for more pre-emptive measures and proactive sensitization of users, most notably following the leak of a controversial EEAS report ringing the alarm bell with regard to disinformation campaigns led by China and Russia. ${ }^{10}$ Facebook ceo Mark Zuckerberg himself called for stricter European regulations of online platforms. ${ }^{11}$

On 10 June 2020, the EU released a Joint Communication on tackling COVID-19 disinformation. It warns of the 'severe consequences' of false news, conspiracy theories, hate speech and fraud, as well as foreign influence operations and disinformation campaigns related to CoviD-19. ${ }^{2}$ With this in mind, it calls for yet another set of non-binding measures to facilitate co-ordinated action, increase digital platforms' responsibility, strengthen media freedom and boost awareness, critical thinking and media literacy. This development is a belated step in the right direction but remains short of strong pre-emptive and accountability mechanisms. It reignites the discussion about the effectiveness of the EU's StratCom policy and the urgent need to protect its information space. The following sections review the prospects of EU strategic communication by analysing two challenges exacerbated by the covid 'infodemic': the toxic effect of conspiracy theories on the EU public sphere, particularly the corona- $5 \mathrm{G}$ hoax, and the influence campaigns promoted by competing geopolitical actors, especially China.

8 Bennett and Livingston 2018, 126-127; Bjola and Papadakis 2020, 3; Faris et al. 2017.

$9 \quad$ Bayer et al. 2019, 6o-72; McKay and Tenove 2020.

10 Emmott 2020; European Parliament 2020.

11 Stolton $202 \mathrm{O}$.

12 European Commission and High Representative of the EU for Foreign Affairs and Security Policy 2020, 2. 
Conspiracy thinking prospers in times of crisis as the anxious public struggles to make sense of the unfolding situation and exert control over a hostile environment. ${ }^{13}$ Conspiracies open discursive spaces to obtain cognitive relief but may prove self-defeating. Research has found, for instance, a statistically significant negative relationship between belief in COVID-19 conspiracy theories and compliance with public health guidance. ${ }^{14}$ The stronger the belief in coronavirus conspiracy thinking, the less adherence to government guidelines and the less willingness to take antibody tests or get vaccinated. ${ }^{15}$ In addition to the risk they present to public health, conspiracy narratives also promote distrust in public institutions and authorities, and thus potentially generate or amplify social instability. Whilst these features create an powerful incentive for some state actors' to use conspiracy theories against rivals, a significant part of conspiracy content is in fact authored and promoted by members of the public sharing their opinions or news articles and videos supporting their cause. This distinction is important as it complicates efforts to counter conspiracy disinformation.

The COVID-19 pandemic has inspired a wide range of conspiracies but the one claiming that the $5 \mathrm{G}$ technology suppresses the immune system, thus making people more vulnerable to the coronavirus, has particularly attracted media attention. ${ }^{16}$ The analysis in this article shows that the Twitter network of $5 \mathrm{G}$ conspiracy-related hashtags has spatially expanded four to five times between March and April 2020 (see Fig. 1). It has also grown content-wise by developing new laminations of the conspiracy theme, most notoriously around the allegedly malefic influence of Microsoft founder and global health philanthropist, Bill Gates. This reveals an important aspect of the process of conspiracy diffusion: they can spread expeditiously and their disruptive effect develops cumulatively with each additional lamination or subtheme.

The discursive community promoting the $5 \mathrm{G}$ coronavirus conspiracy (brown network in Fig. 1) had matured by April to the point that it reached the same size as that supporting the quarantine measures, including EU action ${ }^{17}$ (purple network in Fig. 1). From a communication perspective, this had two important consequences. First, it meant that the health messages that authorities

\footnotetext{
13 Douglas, Sutton and Cichocka 2017.

14 Allington and Dhavan 2020.

15 Freeman et al. 2020.

16 Ahmed et al. 2020; Kelion 2020.

17 European Union 2020.
} 


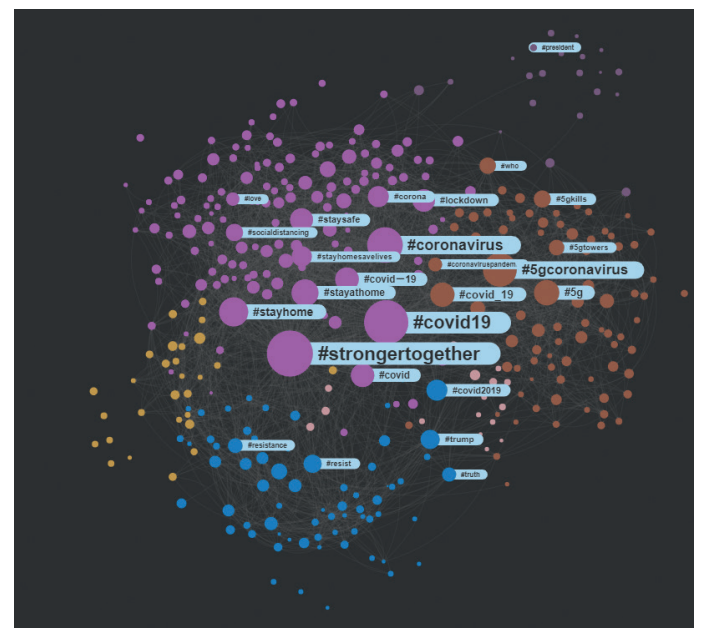

FIGURE 1 The disruptive effect of the ${ }_{5} \mathrm{G}$ conspiracy on Twitter April 2020 SOURCE: AUTHORS' OWN FIGURE GENERATED WITH THE POLINODE SOFTWARE OF SOCIAL NETWORK ANALYSIS

were trying to convey to the public became increasingly contested. Second, it made it difficult for public authorities to debunk and challenge the premises of the conspiracies without risking to further amplify their message. Conspiracy theories are embraced by the public not for their factual value but for their ability to provide a (false) sense of reassurance in times of great uncertainty. Fact-based debunking thus risks elevating their visibility without necessarily undermining their appeal.

The ${ }_{5} \mathrm{G}$ conspiracy case illustrates a more general dilemma that the $\mathrm{EU}$ faces in its strategic communication. One may argue that conspiracies are short lived, without necessarily having a long-lasting effect on the public sphere. Nevertheless, the digital medium has rewritten the rules of mass communication and its vulnerability to toxic disinformation can no longer be ignored, especially on public health issues. ${ }^{18}$ Whilst the specific content of conspiracy theories may not persist, a more enduring effect relates to the epistemic cynicism that they cultivate and encourage among the general public, which has a direct negative effect on the deliberative capacity of democratic systems as well as their ability to respond and adjust themselves in times of crises. ${ }^{19}$

18 Broniatowski et al. 2018; Vosoughi, Roy and Aral 2018.

19 McKay and Tenove 2020. 
The case of CoviD-19-related conspiracies offers the EU some important lessons about how similar forms of digital disinformation could be prevented from corrupting its public sphere in the future. This requires close monitoring of the online space so that conspiracy narratives with the strongest disruptive potential can be promptly detected and pre-bunked, especially the laminations that help expand their thematic content. It also requires special care for the EU not to compromise its fundamental values and normative power in combatting online conspiracies, especially with respect to the truthfulness of the pre-bunking message and the proportionality of the response. Whilst for authoritarian governments, disinformation and public diplomacy are often intertwined, this is not an option for the $\mathrm{EU}$.

Whilst these measures can help contain the dissemination of conspiracy theories in the short term, more systematic efforts (e.g., media literacy, educational campaigns, support for high-quality journalism) ought to be pursued in the long term to foster societal resilience, which some EU Member States already have been advocating since $2015 .{ }^{20}$ As EU High Representative Josep Borrell remarks, 'Disinformation in times of the coronavirus can kill..21 Digital propaganda could be thus seen as an outside 'virus' that invades the 'informational body' of the target country and then uses the 'chemical machinery' of the host to keep itself alive. ${ }^{22}$ Proactive measures play the role of the antiviral drugs, which do not destroy the virus but inhibit its development. Cognitive resilience, on the other hand, works as a vaccine and seeks to produce enough antibodies so that further 'viral infections' can be prevented.

Whilst the $5 \mathrm{G}$ case underlines the internal dangers of disinformation and the need for cognitive resilience, such threats are reinforced by external actors who engage in public diplomacy competition and seek geopolitical gains. Major powers have politicised the COvID-19 crisis, which highlights the very fine line between public diplomacy and disinformation. Direct and open attacks on international institutions and their handling of the pandemic not only have undermined the EU's communication but have also showcased major powers' willingness to disrupt global health governance for domestic purposes. The future of European stability thus rests not only on ensuring societal resilience

\footnotetext{
$20 \quad$ Lidegaard et al. 2015 .

21 European Commission 2020.

22 Bjola and Papadakis 2o2o, 6.
} 
to disinformation and conspiracy theories but also on confronting external public diplomacy campaigns which threaten European health provisions, economic recovery and geoeconomic strength.

In January and February 2020, Germany alongside France, Latvia, Estonia and even Italy had sent more than 30 tons of protective equipment to China to support the government's fight against the virus. However, the EU's and its Member States' support did not make the headlines and their response was instead heavily criticised. ${ }^{23}$ In contrast, the provision of medical supplies by China and Russia to crisis-stricken European countries such as Greece, Italy and Serbia was very publicly promoted. ${ }^{24}$ This seemingly ordinary public diplomacy tool has strong geopolitical implications. Through 'mask diplomacy', China attempts to be a foreign attempt to portray itself as a humanitarian partner and global leader and to strengthen its political and economic foothold in vulnerable parts of Europe. It is also aimed at domestic consumption, reinforcing the message that the crisis is under control and countering criticism of its own handling of the virus.

China's mask diplomacy was greeted with enthusiasm by some leaders in the EU's strategic neighbourhood, exemplified by the case of the Serbian President, who directly and openly contrasted Chinese support with a lack of 'European solidarity'. ${ }^{25}$ When reports came out that Chinese assistance to European countries was accompanied by pressure to officially praise Chinese efforts, public backlash ensued. ${ }^{26}$ Indeed, the politicisation of European solidarity or lack thereof touches on a fundamental premise of the European project and, therefore, represents a core challenge to European 'resilience'. For this reason, it is also an easy target of influence campaigns, illustrated by Eurosceptics' and external actors' use of this narrative. In Germany, foreign deception added fuel to right-wing and left-wing conspiracy theories about the government's plans to exploit the corona crisis for advancing its powers, ${ }^{27}$ which highlights the dangerous combined effects of internal and external disinformation.

Notwithstanding the perception that European institutions were slow in supplying medical equipment, the European response was substantial - but the message did not outplay competing discourses of lack of European solidarity or reaction. Even though the Eu's strategic communication efforts are

23 Herszenhorn and Wheaton 2020; Greer 2020; Rankin 2020.

24 Bechev et al. 2020; Ministry of Foreign Affairs of the Hellenic Republic 2020; Sylvers and Pancevski 2020.

25 Euractiv with AFP 2020; Walker 2020.

26 Apuzzo 2020; Bause 2020; European Parliament 2020.

27 Goßner 2020. 
laudable, in particular the East StratCom Task Force's coverage of corona-related disinformation, their impact in the information battle is far from clear. When referring to the team addressing pro-Kremlin disinformation, a senior official from the EEAS already warned last year: 'We need similar but more adapted capacity to deal with the other major challengers of our approaches, which is China. They are much smarter, much sharper. ${ }^{28}$

Simultaneously, 'corona diplomacy' has taken another toll on transatlantic relations, global governance and multilateralism. The EU is caught in the crossfire of US and Chinese counternarratives on the crisis, the role of the World Health Organization (wHO), and the paralysis of the UN Security Council, Group of 7 and Group of 2o. It becomes clear, as Josep Borrell notes, that the COVID-19 crisis emphasized the need for a multidimensional approach to 'corona diplomacy' which has at its heart 'a geo-political component including a struggle for influence through spinning and the politics of generosity'. ${ }^{29} \mathrm{In}$ fact, the lack of US leadership in this crisis constitutes an opportunity for the EU to assert itself as a global player providing leadership in critical times.

The corona crisis has revealed that disinformation poses serious threats not only to European solidarity and democracy, public trust in institutions and societal security and stability but also to Europeans' health and Europe's geoeconomic strength. Furthermore, it has highlighted the fine line between public diplomacy and harmful disinformation, which the EU will need to calibrate in its strategic communication.

Conspiracy theories are a particularly toxic kind of disinformation. Their dissemination is both internalised by the public and reinforced by external actors, which means that they grow rapidly and are extremely difficult to contain. The flourishing of such theories related to CoviD-19, such as the $5 \mathrm{G}$ hoax, shows the public danger they constitute. In addition, external actors such as China have put the Eu's poor strategic communication on the spot by reinforcing conspiracy beliefs and actively promoting their own narrative related to the pandemic in Europe. These developments must be taken seriously, given their important geopolitical and economic implications.

It is urgent that the EU rethinks its strategic communication policy. Investing in societal resilience through media literacy, educational campaigns and

28 Senior official from the EEAs, interviewed in Brussels by the first author, July 2019.

29 Delegation of the European Union to China 2020. 
support for high-quality journalism should remain a policy priority. However, binding ethically guided pre-emptive measures capable of containing and neutralising disinformation campaigns and foreign influence operations in real time is also critical. More than adapting to the digital milieu, the EU must act as the gatekeeper of Europeans' safety and stability by designing an impactful online governance framework.

\section{Bibliography}

Ahmed, Wassim, Joseph Downing, Marc Tuters and Peter Knight. 'Four Experts Investigate How the $5 \mathrm{G}$ Coronavirus Conspiracy Theory Began'. The Conversation, 11 June 2020. https://theconversation.com/four-experts-investigate-how-the-5gcoronavirus-conspiracy-theory-began-139137.

Allington, Daniel and Nayana Dhavan. The Relationship between Conspiracy Beliefs and Compliance with Public Health Guidance with Regard to COVID-19 (London: Centre for Countering Digital Hate, 2020). https://kclpure.kcl.ac.uk/portal/en/publica tions/the-relationship-between-conspiracy-beliefs-and-compliance-with-public -health-guidance-with-regard-to-covid19(734ca397-6a4d-42o8-bc1a-f3da12 fo4628)/export.html.

Apuzzo, Matt. 'Pressured by China, E.U. Softens Report on Covid-19 Disinformation'. The New York Times, 24 April 2020. https://www.nytimes.com/2020/04/24/world/ europe/disinformation-china-eu-coronavirus.html.

Bause, Margarete. 'Schriftliche Frage an die Bundesregierung zu chinesischen Einflussnahmeversuchen auf deutsche Regierungsmitarbeiter*innen'. 22 April 2020. https://www.margarete-bause.de/de/article/135.schriftliche-frage-an-die-bundes regierung-zu-chinesischen-einflussnahmeversuchen-auf-deutsche-regierungsmi tarbeiter-innen.html.

Bayer, Judit, Natalija Bitiukova, Petra Bard, Judit Szakacs, Alberto Alemanno and Erik Uszkiewicz. Disinformation and Propaganda-Impact on the Functioning of the Rule of Law in the EU and Its Member States. Policy Department for Citizens' Rights and Constitutional Affairs, Directorate General for Internal Policies of the Union, February 2019. http://www.europarl.europa.eu/RegData/etudes/STUD/ 2019/608864/IPOL_STU(2019)6o8864_EN.pdf.

Bechev, Dimitar, Sophia Besch, Ian Brzezinski, Giovanna De Maio, Michel Duclos, Philippe Le Corre, et al. 'Is China Winning the Coronavirus Response Narrative in the EU?' Atlantic Council, 25 March 2020. https://www.atlanticcouncil.org/blogs/ new-atlanticist/is-china-winning-the-coronavirus-response-narrative-in-the-eu/.

Bennett, W. Lance and Steven Livingston. 'The Disinformation Order: Disruptive Communication and the Decline of Democratic Institutions'. European Journal of Communication 33 (2) (2018), 122-139. DOI 10.1177/o26732311876o317. 
Bjola, Corneliu. 'The Ethics of Countering Digital Propaganda'. Ethics and International Affairs 32 (3) (2018), 305-315. DOI 10.1017/So8926794180oo436.

Bjola, Corneliu and James Pamment. 'Digital Containment: Revisiting Containment Strategy in the Digital Age'. Global Affairs 2 (2) (2016), 131-142. DOI 10.1080/ 2334046o.2016.1182244.

Bjola, Corneliu and Krysianna Papadakis. 'Digital Propaganda, Counterpublics and the Disruption of the Public Sphere: The Finnish Approach to Building Digital Resilience'. Cambridge Review of International Affairs (forthcoming 2020), 1-29. DOI 10.1080/o9557571.2019.1704221.

Broniatowski, David A., Amelia M. Jamison, SiHua Qi, Lulwah AlKulaib, Tao Chen, Adrian Benton, Sandra C. Quinn, et al. 'Weaponized Health Communication: Twitter Bots and Russian Trolls Amplify the Vaccine Debate'. American Journal of Public Health 108 (10) (2018), 1378-1384. DOI 10.2105/AJPH.2018.304567.

Delegation of the European Union to China. 'EU HRVP Josep Borrell: The Coronavirus Pandemic and the New World It Is Creating'. 24 March 202O. https:// eeas.europa.eu/delegations/china/76401/eu-hrvp-josep-borrell-coronavirus -pandemic-and-new-world-it-creating_en.

Douglas, Karen M., Robbie M. Sutton and Aleksandra Cichocka. 'The Psychology of Conspiracy Theories'. Current Directions in Psychological Science 26 (6) (2017), 538542. DOI 10.1177/og63721417718261.

Emmott, Robin. 'Russia Deploying Coronavirus Disinformation to Sow Panic in West, EU Document Says'. Reuters, 18 March 2020. https://uk.reuters.com/article/uk -health-coronavirus-disinformation/russia-deploying-coronavirus-disinformation -to-sow-panic-in-west-eu-document-says-idUKKBN215189.

Euractiv with AfP (Agence France-Presse). 'Serbia Sets the Stage for Beijing's Mask Diplomacy'. Euractiv, 2 April 2020. https://www.euractiv.com/section/china/news/ serbia-sets-the-stage-for-beijings-mask-diplomacy/.

European Commission. 'Coronavirus: EU Strengthens Action to Tackle Disinformation'. Press release, 10 June 2020. https://ec.europa.eu/commission/presscorner/detail/ en/ip_20_10o6.

European Commission and High Representative of the European Union for Foreign Affairs and Security Policy. Tackling COVID-19 Disinformation - Getting the Facts Right. JOIN/2O2O/8/final. 10 June 2020. https://ec.europa.eu/info/sites/info/files/ communication-tackling-covid-19-disinformation-getting-facts-right_en.pdf.

European Parliament. 'EEAS Special Report on the Narratives and Disinformation around the COVID-19/Coronavirus Pandemic: questions/answers (Part 1)'. 30 April 2020. https://multimedia.europarl.europa.eu/en/eeas-special-report-on-the-narra tives-and-disinformation-around-the-covid-19coronavirus-pandemic_I190129-V_v.

European Union. 'The Common Eu Response to COVID-19'. June 2020. https://europa .eu/european-union/coronavirus-response_en. 
Faris, Robert M., Hal Roberts, Bruce Etling, Nikki Bourassa, Ethan Zuckerman and Yochai Benkler. Partisanship, Propaganda, and Disinformation: Online Media and the 2016 U.S. Presidential Election. Berkman Klein Center for Internet \& Society Research Paper, August 2017. http://nrs.harvard.edu/urn-3:HUL.InstRepos:33759251.

Fletcher, Richard, Alessio Cornia, Lucas Graves and Rasmus Kleis Nielsen. Measuring the Reach of 'Fake News' and Online Disinformation in Europe. Reuters Institute for the Study of Journalism, February 2018. https://reutersinstitute.politics.ox.ac .uk/sites/default/files/2018-o2/Measuring\%2othe\%2oreach\%2oof\%2ofake\%20 news $\% 2$ oand $\% 2$ oonline $\% 2$ odistribution\%2oin\%2oEurope\%2oCORRECT\%2O FLAG.pdf.

Freelon, Deen and Chris Wells. 'Disinformation as Political Communication'. Political Communication 37 (2) (2020), 145-156. DOI 10.1080/10584609.2020.1723755.

Freeman, Daniel, Felicity Waite, Laina Rosebrock, Ariane Petit, Chiara Causier, Anna East, Lucy Jenner, et al. 'Coronavirus Conspiracy Beliefs, Mistrust, and Compliance with Government Guidelines in England'. Psychological Medicine (2020), 1-30. DOI 10.1017/Soo3329172000189o.

Goßner, Christina. 'Anti-Lockdown Protests in Germany Infiltrated by Far-Right Extremists'. Euractiv, 14 May 2020. https:/www.euractiv.com/section/coronavirus/ news/anti-lockdown-protests-in-germany-infiltrated-by-far-right-extremists/.

Greer, Scott L. 'How Did the E.U. Get the Coronavirus so Wrong?'. The New York Times, 6 April 2020. https://www.nytimes.com/2020/04/o6/opinion/europe-coronavirus .html.

Herszenhorn, David M. and Sarah Wheaton. 'How Europe Failed the Coronavirus Test'. Politico, 7 April 2020. https://www.politico.eu/article/coronavirus-europe -failed-the-test/.

HLEG (High Level Expert Group on Fake News and Online Disinformation). Report of the Independent High-Level Group on Fake News and Online Disinformation. European Commission: Directorate-General for Communication Networks, Content and Technology, March 2018. https://ec.europa.eu/digital-single-market/en/news/ final-report-high-level-expert-group-fake-news-and-online-disinformation.

Jeangène Vilmer, Jean-Baptiste, Alexandre Escorcia, Marine Guillaume and Janaina Herrera. Information Manipulation: A Challenge for Our Democracies. Policy Planning Staff (CAPS) of the Ministry for Europe and Foreign Affairs and the Institute for Strategic Research (IRSEM) of the Ministry for the Armed Forces, Paris, August 2018. https://www.diplomatie.gouv.fr/IMG/pdf/information_manipulation_ rvb_cle838736.pdf.

Kelion, Leo. 'Mast Fire Probe amid 5G Coronavirus Claims'. ввс News, 4 April 2020. https://www.bbc.com/news/uk-england-52164358.

Lidegaard, Martin, Keit Pentus-Rosimannus, Linas Linkevičius and Philip Hammond. EU Strategic Communication Responding to Propaganda: Non-Paper. 8 January 2015. Obtained through interviews conducted in July 2019 in Brussels by the first author. 
Marwick, Alice and Rebecca Lewis. Media Manipulation and Disinformation Online. Data and Society Research Institute, 2017. https://datasociety.net/output/media -manipulation-and-disinfo-online/.

McKay, Spencer and Chris Tenove. 'Disinformation as a Threat to Deliberative Democracy'. Political Research Quarterly (2020), 1-15. DoI 10.1177/1065912920938143.

Ministry of Foreign Affairs of the Hellenic Republic. 'Alternate Minister of Foreign Affairs Attends Reception of Medical Supplies Donated by China'. 21 March 2020. https://www.mfa.gr/en/current-affairs/top-story/alternate-minister-of-foreign -affairs-attends-reception-of-medical-supplies-donated-by-china-athens-21 -march-2020.html.

Nye, Joseph. 'How Sharp Power Threatens Soft Power: The Right and Wrong Ways to Respond to Authoritarian Influence'. Foreign Affairs, 24 January 2018. https://www.foreignaffairs.com/articles/china/2018-o1-24/how-sharp-power -threatens-soft-power.

Rankin, Jennifer. 'Coronavirus Could Be Final Straw for EU, European Experts Warn'. The Guardian, 1 April 2020. https:/www.theguardian.com/world/2020/apr/o1/ coronavirus-could-be-final-straw-for-eu-european-experts-warn.

Stolton, Samuel. 'Zuckerberg Appeals for European Leadership on Platform Regulation'. Euractiv, 19 May 2020. https://www.euractiv.com/section/digital/news/ zuckerberg-appeals-for-european-leadership-on-platform-regulation/.

Sylvers, Eric and Bojan Pancevski. 'Chinese Doctors and Supplies Arrive in Italy'. The Wall Street Journal, 18 March 2020. https://www.wsj.com/articles/chinese-doctors -and-supplies-arrive-in-italy-11584564673.

Tucker, Joshua A., Andrew Guess, Pablo Barberá, Cristian Vaccari, Alexandra Siegel, Sergey Sanovich, Denis Stukal and Brendan Nyhan. Social Media, Political Polarization, and Political Disinformation: A Review of the Scientific Literature. Hewlett Foundation, March 2018. https://hewlett.org/wp-content/uploads/2018/o3/Social -Media-Political-Polarization-and-Political-Disinformation-Literature-Review.pdf.

Vosoughi, Soroush, Deb Roy and Sinan Aral. 'The Spread of True and False News Online'. Science 359 (6380) (2018), 1146-1151. DOI 10.1126/science.aap9559.

Walker, Shaun. 'Coronavirus Diplomacy: How Russia, China and EU Vie to Win over Serbia'. The Guardian, 13 April 2020. https:/www.theguardian.com/world/2020/ apr/13/coronavirus-diplomacy-how-russia-china-and-eu-vie-to-win-over-serbia.

\section{Sophie L. Vériter}

is a Doctoral Researcher at the Institute of Security and Global Affairs (ISGA) at the University of Leiden, The Hague. Her research focuses on European Union (EU) policy-making, with a specific interest in strategic communication and the EU's eastern neighbourhood. She graduated with a MPhil in European Politics and Society from the University of Oxford, where she works as a Research Assistant for the 'Europe's Stories' project at the European Studies 
Centre. Previously, she worked as a consultant for the EU's public diplomacy in the Eastern Partnership countries.

\section{Corneliu Bjola}

is an Associate Professor in Diplomatic Studies at the University of Oxford, and Head of the Oxford Digital Diplomacy Research Group. His research focuses on the impact of digital technology on the conduct of diplomacy with a focus on strategic communication, digital influence and methods for countering digital propaganda. His most recent publication is the co-edited volume (with Ruben Zaiotti) Digital Diplomacy and International Organizations: Autonomy, Legitimacy and Contestation (Routledge forthcoming 2020).

\section{Joachim A. Koops}

is a Professor of Security Studies and Scientific Director of the Institute of Security and Global Affairs (ISGA) at the University of Leiden, The Hague, The Netherlands. His research focuses on European diplomacy, European Union foreign and security policy, the United Nations' role in peace, and security and global security governance. 